\title{
Epidemiological and Clinical Features of Diabetic Foot in Cotonou
}

\author{
Annelie Kerekou Hode, François Djrolo, Daniel Amoussou-Guenou \\ University Clinic of Endocrinology and Metabolism CNHU/HKM Cotonou, University of Abomey-Calavi, \\ Cotonou, Benin \\ Email: kerekouannelie@yahoo.fr, fdjrolo@yahoo.fr, danielamousguen@yahoo.fr
}

Received 19 April 2015; accepted 3 August 2015; published 6 August 2015

Copyright (C) 2015 by authors and Scientific Research Publishing Inc.

This work is licensed under the Creative Commons Attribution International License (CC BY). http://creativecommons.org/licenses/by/4.0/

c) (i) Open Access

\begin{abstract}
This was a retrospective and descriptive study conducted from 1 July 2006 to 31 July 2011 and carried on 122 cases of diabetic foot collected a total of 706 diabetic patients hospitalized over a period of 5 years. Objective: To study the characteristics of diabetic feet in Cotonou. Results: The mean age of patients was 58.05 years \pm 10.65 years, ranging from 35 years to 70 years. The sex ratio was 1.5. Duration of diabetes before the onset of diabetic foot was 11 years. The overall prevalence of diabetic foot was $21.53 \%$. Of these, $95 \%$ had neuropathy, $\mathbf{7 0 . 4 0 \%}$ had arterial disease and all had a foot infection. The amputation rate was $31.96 \%$ and the mortality rate was $17.21 \%$. Conclusion: The occurrence of diabetic foot is earlier than in the West, and hence there is a need for early treatment of diabetes.
\end{abstract}

\section{Keywords}

Diabetes, Diabetic Foot, Benin, Africa

\section{Introduction}

Diabetes mellitus undergoes an extensive epidemiological explosion both in developed countries and in the Third World. It is estimated that over 120 million people worldwide suffer from diabetes and that by 2025 , the diabetic population will reach 333 million people worldwide [1]. Diabetes mellitus is a chronic disease, source of complications that spares no organ; the foot of the diabetic is one of the most frequently affected. This is the primary cause of a non-traumatic amputation member [2]. Approximately $15 \%-20 \%$ of diabetics will be inpatient for complications of foot during their illness [3] [4]. The occurrence of diabetic foot in the service allows us to initiate this study on the characteristics of the diabetic foot. 


\section{Patients and Method}

Setting: Benin is a low income francophone country of West Africa. Its population is 10.2 million inhabitants and its GDP 8.307 billion US dollars. The per capita income was 790 dollars a year and poverty rate was $36.2 \%$ in 2013. Life expectancy was 59 years in 2012 [5]. Health system in Benin is pyramidal in three levels. There is no social care, health care is not free of charge for the patients or their families. Its National Teaching Hospital "HKM" is the reference center and the largest in Benin. It is located in Cotonou, the economic capital of Benin. It has a capacity of 642 beds. The Department of Endocrinology, Metabolic Diseases and Nutrition has a capacity of 14 beds and receives an average of 160 patients per year.

Method: This was a retrospective, study, which took place July 1, 2006 to July 31, 2011. Seven hundred and six diabetic patients among which 152 had diabetic foot were in-patient during the study period and 30 cases could not be included. One hundred twenty-two patients could not be inclued in our study. Analyses focused on demographic and anthropometric characteristics (BMI), the factors favoring the occurrence of foot injuries and appearance of the injuries. Bacteriological samples of the lesions were made by swabbing. The samples were placed on a transport medium of live bacteria and seeded agar sheep blood and eosin methylene blue (EMB). The result was read 48 hours later to determinethe antibiotic predisposition. We could not utilize systolic pressure index which is delete examining; least expensive technique, for we do not have it. Doppler ultrasonography of the lower limbs was requested, depending on the disease duration and clinical signs, to assess the vascularization, location and extent of any stenosis of the arteries. It has been achieved in 98 patients. The peripheral arterial disease (PAD) was diagnosed whenthe stenosis was greater than or equal to $50 \%$ at the femoral or tibial arteries. Antibiotic therapy was probabilistic first line and then targeted after results of bacteriological analyzes. The amputation was indicated in cases of lesion progression despite medical treatment.

The data analysis was performed with Epi-Info 3.3.2 software. Qualitative variables were described by using percentages and confidence intervals and quantitative variables by using the mean and standard deviation. The frequency comparisons were made by using Chi test Two and average comparisons with Student's t test. A p-value less than or equal to 0.05 was considered statistically significant.

\section{Results}

\subsection{Socio-Demographic Characteristics}

The mean age of patients was 58.05 years \pm 10.65 years, ranging from 35 years to 70 years. The sex ratio was 1.5. The overall prevalence of diabetic foot was $21.53 \%$ of hospitalized diabetic patients.

\subsection{Clinical Features}

The foot injuries occurred spontaneously in $55.7 \%$ of patients with neuropathy, the most common extrinsic initiating factors were trauma (14.8\%) and thermal burns (11.5\%) (Table 1). Among them, 122 cases were operated and 95\% had neuropathy (Figure 1). All 122 patients had a foot infection (Figure 2). Doppler ultrasonography of the leg arteries was performed (Figure 3 and Figure 4) in 98 patients to classify foot lesions as ischemic $70.4 \%(n=69)$ (Figure 5) or non-ischemic $29.6 \%(n=29)$.

Diabetes mean duration did not impact the occurrence of ischemic injury $(p=0.53)$. The weight did not influence the types of injury. There were no specific bacteria that corelated with the different types of soft tissue injury. Osteitis was more common in patients with ischemic foot $(p=0.03)$ (Table 2).

\subsection{Therapeutic Features}

The response to treatment was more favorable in patients with non-ischemic diabetic foot $(\mathrm{p}=0.002)$. Mortality was $27.5 \%$ in patients with ischemic diabetic foot and $6.9 \%$ in patients with non-ischemic diabetic foot $(\mathrm{p}=$ 0.002). Hospital stay was shorter in patients with non-ischemic diabetic foot (Table 2).

\section{Discussion}

It was about a hospital study, which was a bias of recruitement. Its character retropestive was at the base of loss of information among some patients.

This study has allowed us to analyze the epidemiological characteristics and outcomes of the treatment of 


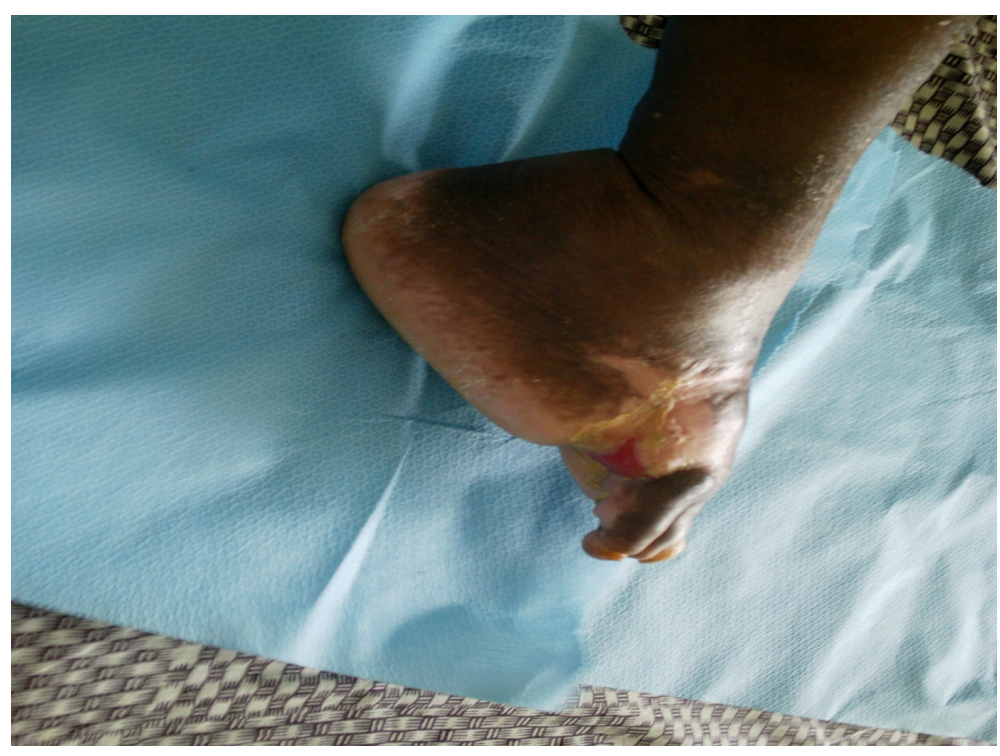

Figure 1. Charcot neuroarthropathy.

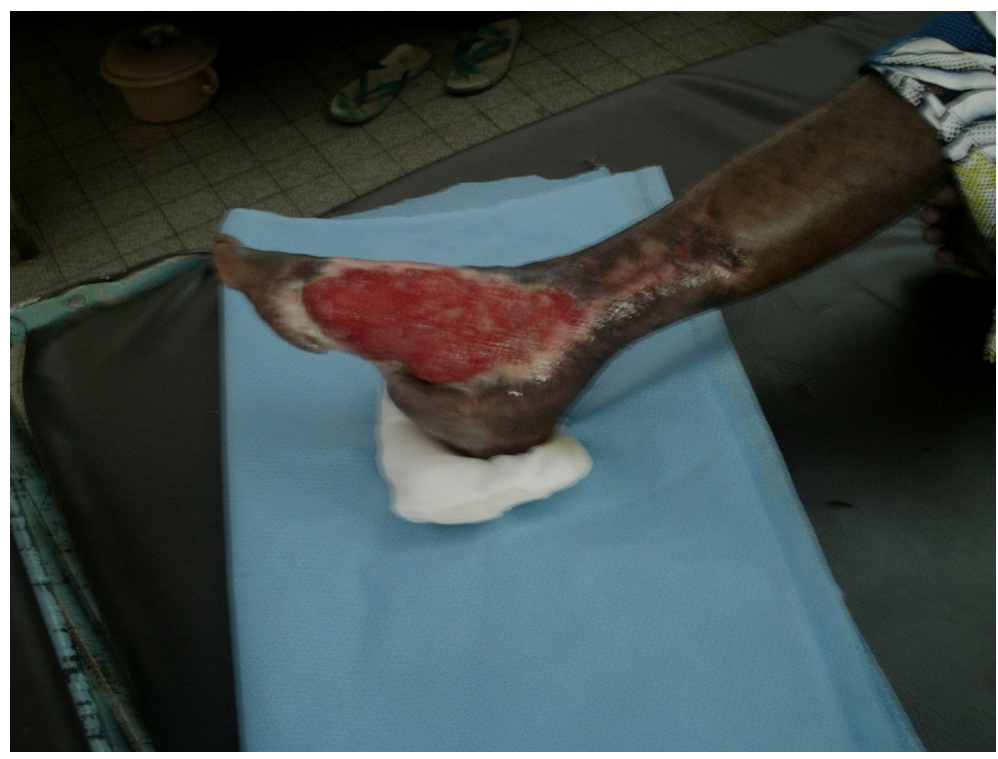

Figure 2. Diabetic foot infection.

Table 1. Contributing factors the occurrence of injuries of the foot in our patients.

\begin{tabular}{ccc}
\hline & Number & Percentage (\%) \\
\hline Spontaneous appearance on neuropathic foot & 68 & 55.7 \\
Wearing tight shoes & 10 & 8.2 \\
Gesture of pedicure & 7 & 5.7 \\
Burning domestic & 14 & 11.5 \\
Motorcycle exhaust pipe burn & 5 & 4.1 \\
Traumatic pedicure & 18 & 14.8 \\
Total & 122 & 100 \\
\hline
\end{tabular}




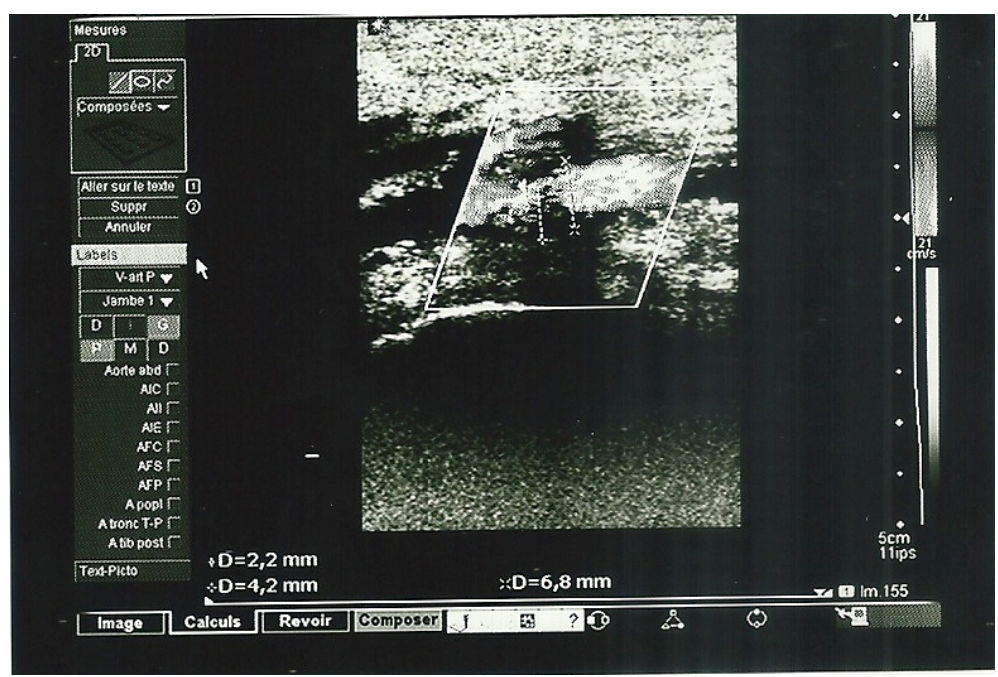

Figure 3. Ultrasound focused stenosis of more than $60 \%$.

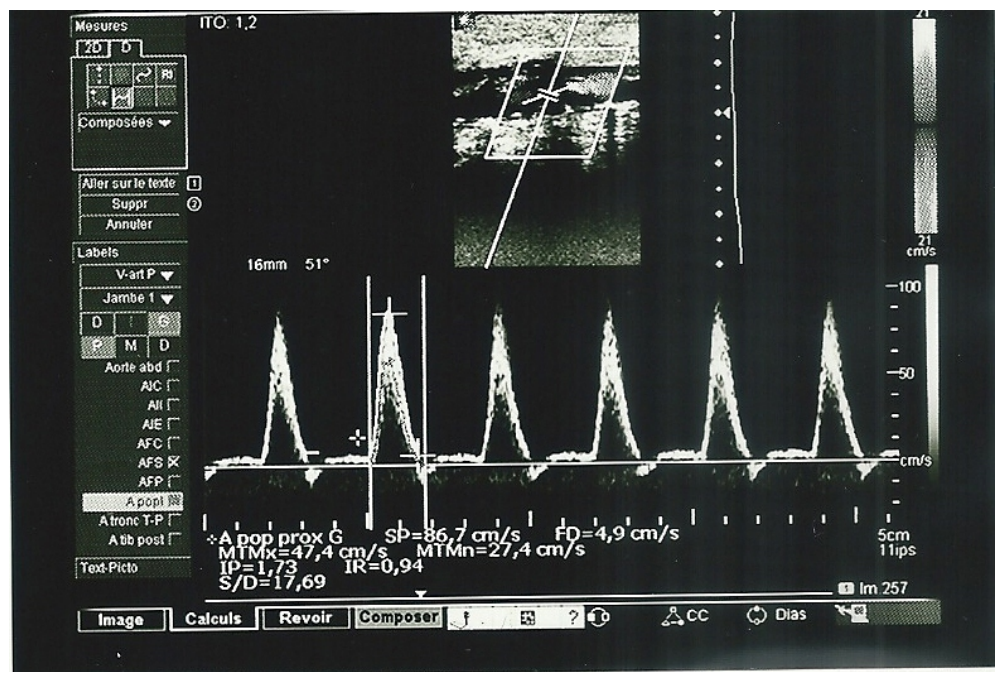

Figure 4. Doppler flow acceleration of the point of stenosis measured at 86.7 $\mathrm{cm} / \mathrm{sec}$.

diabetic foot in our unit. We compared our results with those of the literature including African writers working in conditions similar to ours.

\subsection{Prevalence}

The inclusive prevalence of diabetic feet in sub-Saharan Africa varied between 13\% and 23\% [6]-[11] (Table 3). These prevalences were similar to those found in the United States by Frykberg et al., in Iowa, and Jeffcoate et $a l$. in the United Kingdoms who reported that about $15 \%-20 \%$ of diabetics will be hospitalized for foot complications during their illness [4] [12]. The mean age of diabetic foot occurring in sub-Saharan Africa was between 53 and 60 years. The mean duration of diabetes before the onset of diabetic foot was less than 10 years, while in Western countries, the diabetic foot is observed after duration of diabetes of almost 20 years [13].

Diabetic foot is more prevalent in patients having distinct but interacting factors: neuropathy and arteriopathy are two secondary complications of diabetes, and infection is a decompensation factor. In our study, lesions were favored by foot trauma (14.8\%), domestic thermal burns $(11.5 \%)$ or skin burn by motorcycles $(4.1 \%)$, wearing tight shoes $(8.2 \%)$, traumatic pedicures $(5.7 \%)$. In the majority of cases $(55.7 \%)$ lesions spontaneously occurred on neuropathic foot and sometimes when patients walked barefoot. These predisposing factors have 
Table 2. Comparison of clinical and therapeutic of ischemic and non-ischemic diabetic foot lesions.

\begin{tabular}{|c|c|c|c|}
\hline & \multicolumn{2}{|c|}{ Diabetic Foot } & \multirow{2}{*}{$\mathrm{P}$} \\
\hline & Ischemic $\mathrm{n}=69(\%)$ & Non Ischemic $n=29(\%)$ & \\
\hline Mean age (years) & $58.86 \pm 9.79$ & $58.14 \pm 12.91$ & 0.76 \\
\hline Duration of diabetes (years) & $11.55 \pm 6.80$ & $10.45 \pm 10.22$ & 0.53 \\
\hline \multicolumn{4}{|l|}{ BMI $^{\&}$} \\
\hline$<25$ & $33(50.77)$ & $17(58.60)$ & \\
\hline $25-30$ & $22(33.85)$ & $8(27.60)$ & 0.77 \\
\hline$\geq 30$ & $10(15.38)$ & $4(13.80)$ & \\
\hline \multicolumn{4}{|l|}{ Clinical and radiological aspects of the lesions } \\
\hline Dry Gangrene & $26(37.70)$ & $8(27.60)$ & \\
\hline Wet Gangrene & $32(46.40)$ & $11(37.90)$ & 0.07 \\
\hline Abscess & $8(11.60)$ & $10(34.50)$ & \\
\hline Diabetic foot ulcer & $3(4.30)$ & 0 & \\
\hline Osteitis & $38(71.70)$ & $9(47.40)$ & 0.03 \\
\hline \multicolumn{4}{|l|}{ The most common bacterial strains } \\
\hline Escherichia coli & $9(14.10)$ & $6(25.00)$ & 0.34 \\
\hline Enterococcus & $9(14.10)$ & $3(12.50)$ & 0.71 \\
\hline Klebsiella & $11(17.20)$ & $2(8.30)$ & 0.23 \\
\hline$\underline{\text { Staphylococcus aureus }}$ & $8(12.50)$ & $4(16.70)$ & 0.76 \\
\hline Pseudomonas & $7(10.90)$ & $1(4.20)$ & 0.27 \\
\hline \multicolumn{4}{|l|}{ Microangiopathy } \\
\hline Nephropathy & $32(62.70)$ & $6(33.30)$ & 0.02 \\
\hline Retinopathy & $40(69.00)$ & $12(48.00)$ & 0.13 \\
\hline \multicolumn{4}{|l|}{ Treatment and outcome } \\
\hline Under medical cure & $19(27.50)$ & $19(65.50)$ & \\
\hline Healing after foot amputation & $12(17.40)$ & $5(17.20)$ & 0.002 \\
\hline Healing after leg amputation at or above the knees & $19(27.50)$ & $3(10.30)$ & \\
\hline Mortality & $19(27.50)$ & $2(6.90)$ & \\
\hline Duration (days) & $60.54 \pm 55.96$ & $44.90 \pm 33.43$ & 0.003 \\
\hline
\end{tabular}

The BMI was calculated for 65 ischemia's cases.

previously been reported by European and African authors [1] [7].

\subsection{Peripheral Vascular Disease}

The diagnosis of PAD was delete based on echo-Doppler of the lower limbs. It was found in $70.40 \%$ of patients with diabetic foot (Figure 1). Amoussou-Guénou et al. reported a frequency of 32\% and Lokrou also reported a frequency of $55 \%$ on a clinical assessment [8] [11]. We observed in our study a better accesilitiy to diagnostic tests in relation to that of Amoussou-Guénou from 1995 to 1999 [8].

The other etiological factor found was peripheral neuropathy. It results from a long term hyperglycemia. Some of the glucose is converted by aldose reductase to sorbitol. Sorbitol is then reduced by the sorbitol 


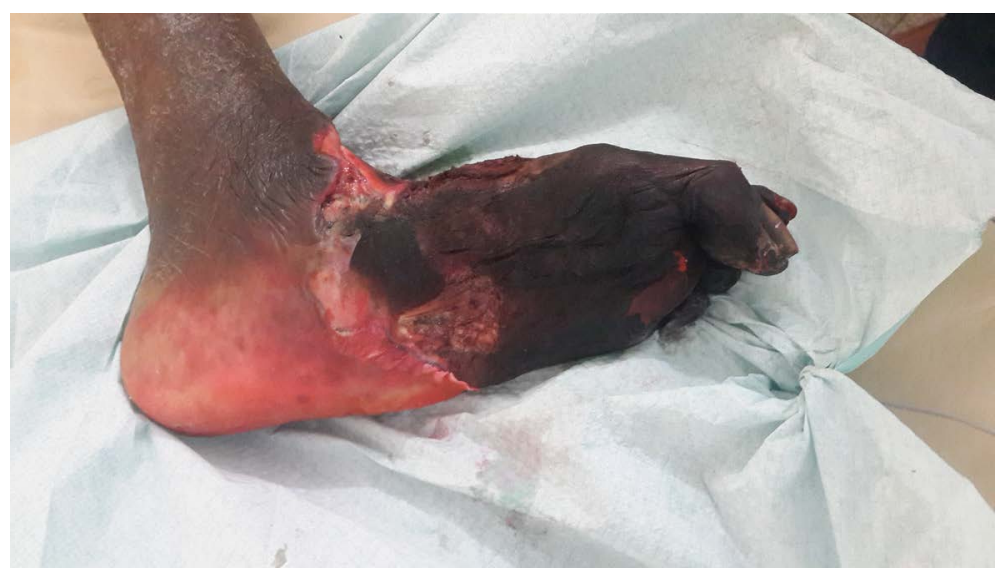

Figure 5. Ischemic foot.

Table 3. Comparing clinical and treatment of diabetic foot with other authors sub-Saharan.

\begin{tabular}{|c|c|c|c|c|c|c|c|}
\hline $\begin{array}{l}\text { City } \\
\text { Authors }\end{array}$ & $\begin{array}{l}\text { Yaoundé } \\
\text { Nouedoui }\end{array}$ & $\begin{array}{l}\text { Brazzaville } \\
\text { Monabéka }\end{array}$ & $\begin{array}{c}\text { Cotonou } \\
\text { Amoussou- } \\
\text { Guenou }\end{array}$ & $\begin{array}{l}\text { Yaoundé } \\
\text { Tchakonté }\end{array}$ & $\begin{array}{l}\text { Niamey } \\
\text { Sani }\end{array}$ & $\begin{array}{l}\text { Abidjan } \\
\text { Lokrou }\end{array}$ & $\begin{array}{l}\text { Cotonou } \\
\text { Our Study }\end{array}$ \\
\hline Years & $1992-1997$ & 1995-1999 & 1995-1999 & $\begin{array}{c}\text { June-oct } \\
2002\end{array}$ & $2001-2003$ & $2002-2008$ & 2006-2011 \\
\hline Groups & 5315 & 1654 & 420 & 300 & 648 & - & 706 \\
\hline Diabetic foot & $23 \%$ & $14.9 \%$ & $16.66 \%$ & $13 \%$ & $13.9 \%$ & 241 & $21.53 \%$ \\
\hline Mean age (years) & - & 56.8 & 60 & 57.9 & 53 & 56.8 & 58.05 \\
\hline $\begin{array}{l}\text { Duration of the } \\
\text { diabetes (years) }\end{array}$ & - & 8 & 10 & 6.6 & $52.2 \%(<5)$ & 8.2 & 11 \\
\hline Sex-ratio & - & - & 2.4 & - & 2.46 & 1.6 & 1.5 \\
\hline $\begin{array}{c}\text { Enabling Factors of } \\
\text { Neuropathy } \\
\text { arterial disease } \\
\text { Infection }\end{array}$ & $\begin{array}{l}- \\
- \\
-\end{array}$ & $\begin{array}{l}- \\
- \\
-\end{array}$ & $\begin{array}{l}- \\
- \\
-\end{array}$ & $\begin{array}{l}- \\
- \\
-\end{array}$ & $\begin{array}{l}- \\
- \\
-\end{array}$ & $\begin{array}{c}94.2 \% \\
55.8 \% \\
99 \%\end{array}$ & $\begin{array}{c}55.7 \% \\
70.40 \% \\
100 \%\end{array}$ \\
\hline Bacterial strains & $\begin{array}{l}\text { Staphylococci } \\
\text { Proteus } \\
\text { mirabilis } \\
\text { Entérococci }\end{array}$ & $\begin{array}{l}\text { Staphylocci doré } \\
\text { Streptococcus }\end{array}$ & - & - & $\begin{array}{l}\text { Staphylococcus } \\
\text { Klebsiella } \\
\text { Streptococcus }\end{array}$ & $\begin{array}{c}\text { Enterobacteriaceae } \\
\text { Micrococcaceae } \\
\text { Streptococcaceae }\end{array}$ & $\begin{array}{l}\text { Enterococcus } \\
\text { Klebsiella } \\
\text { Staphylococcus } \\
\text { Pseudomonas } \\
\text { Escherichia coli } \\
\end{array}$ \\
\hline Ostetitis & - & - & $38.09 \%$ & - & - & - & $38.52 \%$ \\
\hline Amputation & $6.3 \%$ & $41 \%$ & $20 \%$ & - & $41 \%$ & $36 \%$ & $31.96 \%$ \\
\hline Mortality & - & $16.7 \%$ & - & - & $16 \%$ & - & $17.21 \%$ \\
\hline Length of stay (days) & - & 28.5 & 41 & - & 28.5 & - & 44.9 to 60.54 \\
\hline
\end{tabular}

dehydrogenase fructose ("polyol pathway"). Nerve tissue is devoid of sorbitol dehydrogenase and consequently, sorbitol accumulates in nerve fibers and in Schwann cells [14]-[16]. The exposure of motor nerves results in an atrophy of the intrinsic foot muscles.

The atrophy is accompanied by a retraction of the toe, because of a disparity

between flexor and extensor muscles of the toes (Figure 2). In our study it was found in 95\% of patients, similar to that found by Lokrou in Ivory Coast in 2013: 94.2\% [11]. In the prospective study Lipsky et al. [17], the statement regarding 1.6 seeds is unclear per sample close to a flora of "city" as a hospital flora; Staphylococcus aureus was found in $30 \%$ of cases. In our study 3 - 5 strains of bacteria was this in each patients. The polymicrobial infection has been reported by other authors in the sub-Saharan literature [7] [9]-[11] (Table 3). Although the infection has been present in all of our patients, the appearance of the lesions and the local cir- 
cumstances were not possible to achieve $100 \%$ setting bacteriological cultures. However, the proportion of positive cultures among the 122 samples taken, testimony to the quality of the samples. The most frequently isolated bacteria were staphylococci and enterococci (Table 3). These same bacteria have been reported in studies in Malaysia [18], Algeria [19], India [20] and the US [21].

\subsection{Therapeutic}

In our health care system, the diagnostic test and treatment were prescrib accordind to financial means patients. which explains the diagnostic and therapeutic delay and the high rates of complications.

The treatment of diabetic foot is a multidisciplinary one involving different specialties. Vascular and infectious balance of diabetic ulcers allows us to offer appropriate treatment. Basic principles should be respected: dump, debridement, infection control and glycemic control. Revascularization techniques are rare in subSaharan Africa, where lower limb amputation is the most common choice in cases of extensive necrosis, uncontrolled infection, ischemia or technical barriers to distal revascularization [22]. The frequency of amputations varies from $6.3 \%$ to $41 \%$ [6]-[11] in sub-Saharan publications (Table 3), while in diabetic patients who regularly consult a Diabetic Foot Clinic, the annual rate of leg amputation is only $0.11 \%$ in the West [15].

\section{Conclusion}

Diabetes is becoming pandemic. In SSA, diabetic foot lesions are common, occurring early diabetes due to undiagnosed disease or poor. This is a serious complication that results in mortality, morbidity and disability. It represents a public health problem that will be increasingly important. It is necessary to continue raising awareness of diabetes in order to improve care and reduce or delay its complications. But the lack of education structure and low socio-economic level of our people constitute major obstacles to effective prevention of diabetes complications.

\section{References}

[1] Besse, J.L., Leemrijse, T. and Deleu, P.A. (2011) Diabetic Foot: The Orthopedic Surgery Angle. Orthopaedics \& Traumatology, Surgery \& Research: OTSR, 97, 314-329. http://dx.doi.org/10.1016/j.otsr.2011.03.001

[2] Grimaldi, A., Cornet, P., Masseboeuf, N., Popelier, M. and Sachon, C. (1997) Guide pratique du diabète. Collection Médiguide du Généraliste, Paris.

[3] Frykberg, R.G. (2002) Diabetic Foot Ulcers: Pathogenesis and Management. American Family Physician, 66, 16551662 .

[4] Frykberg, R.G., Armstrong, D., Giurini, J., Edwards, A., Kravette, M., Kravitz, S., et al. (2000) Diabetic Foot Disorders: A Clinical Practice Guideline. Data Trace Publishing Company, Towson.

[5] World Bank (2014) Benin: Country at a Glance. http://www.worldbank.org/en/country/benin

[6] Nouedoui, C., Teyang, A. and Djoumessi, S. (2003) Epidemiological Study and Treatment of the Diabetic Foot in Yaounde Diabetic Center, Cameroon. Tunisie Medical, 81, 20-25.

[7] Monabeka, H.G. and Nsakala-Kibangou, N. (2001) Epidemiological and Clinical Aspects of the Diabetic Foot at the Central University Hospital of Brazzaville. Bulletin de la Société de pathologie exotique, 94, 246-248.

[8] Amoussou-Guenou, K.D., Zannou, D.M., Ade, G., Djrolo, F., Avimadje, M., Bigot, A., Koffi-Tessio, A. and Houngbe, F. (2006) Morbidity of Diabetic Foot in Internal Medicine CNHU HKM, Cotonou. Mali Medical, 21, 4-7.

[9] Tchakonté, B., Ndip, A., Aubry, P., Malvy, D. and Mbanya, J.C. (2005) The Diabetic Foot in Cameroon. Bulletin de Société de Pathologie Exotique, 98, 94-98.

[10] Sani, R., Ada, A., Bako, H., Adehossi, E., Metchendje Noundui, J., Baoua, B.A., Seibou, A. and Kolle, L. (2010) Le pied diabétique: Aspects épidémiologiques, cliniques et thérapeutiques à l'hôpital national de Niamey. A propos de 90 cas. Médecine d' Afrique Noire, 57, 172-176.

[11] Lokrou, A., Memel, A.T. and Dago, K.P. (2013) Bacteriology of Diabetic Foot Lesions in Ivory Coast. Médecine des Maladies Métaboliques, 7, 477-481.

[12] Jeffcoate, W.J. and Harding, K.G. (2003) Diabetic Foot Ulcers. The Lancet, 361, 1545-1551. http://dx.doi.org/10.1016/S0140-6736(03)13169-8

[13] Van Damme, H.L.R. (2005) Le pied diabétique. Revue médicale de Liège, 60, 516-525.

[14] Nathan, D. (1993) Long-Term Complications of Diabetic Mellitus. New England Journal of Medicine, 328, 1676-1785. 
http://dx.doi.org/10.1056/NEJM199306103282306

[15] Van Damme, H., Paquet, P., Maertens De Noordhout, B. and Damas, P. (1994) Le pied diabétique, étiopathogénie, prévention et traitement. Revue Médicale de Liège, 49, 1-13.

[16] Dyck, P., Zimmerman, B., Vilen, T., et al. (1988) Nerve Glucose, Fructose, Sorbitol, Myoinositol and Fiber Degeneration and Regeneration in Diabetic Neuropathy. New England Journal of Medicine, 319, 542-548. http://dx.doi.org/10.1056/NEJM198809013190904

[17] Lipsky, B.A., Baker, P.D., Landon, G.C. and Fernau, R. (1997) Antibiotic Therapy for Diabetic Foot Infections: Comparison of Two Parenteral-to-Oral Regimens. Clinical Infectious Diseases, 24, 643-648. http://dx.doi.org/10.1093/clind/24.4.643

[18] Yoga, R., Khairul, A., Sunita, K. and Suresh, C. (2006) Bacteriology of Diabetic Foot Lesions. Medical Journal of Malaysia, 61, 14-16.

[19] Merad, A.S. (1993) Infection of Diabetic Foot Lesions: Bacterial Etiology, Place of Anaerobic Bacteria, Therapeutic Consequences. Archives de l'Institut Pasteur d'Algérie, 59, 127-140.

[20] Gadepalli, R., Dhawan, B., Sreenivas, V., Kapil, A., Ammini, A.C. and Chaudhry, R. (2006) A Clinico-Microbiological Study of Diabetic Foot Ulcers in an Indian Tertiary Care Hospital. Diabetes Care, 29, 1727-1732. http://dx.doi.org/10.2337/dc06-0116

[21] Ge, Y., MacDonald, D., Hait, H., Lipsky, B., Zasloff, M. and Holroyd, K. (2002) Microbiological Profile of Infected Diabetic Foot Ulcers. Diabetic Medicine, 19, 1032-1034. http://dx.doi.org/10.1046/j.1464-5491.2002.00696 1.x

[22] Van Damme, H., Rorive, M., Maertens De Noordhout, B.M., et al. (2001) Amputations in Diabetic Patients, a Plea for Footsparing Surgery. Acta Chirurgica Belgica, 101, 123-129. 